\title{
Supply and demand, allocation and wage inequality: an international comparison
}

Citation for published version (APA):

Dupuy, A., \& Borghans, L. (2003). Supply and demand, allocation and wage inequality: an international comparison. Researchcentrum voor Onderwijs en Arbeidsmarkt, Faculteit der Economische Wetenschappen. ROA Research Memoranda No. 8E https://doi.org/10.26481/umaror.200308E

Document status and date:

Published: 01/01/2003

DOI:

10.26481/umaror.200308E

Document Version:

Publisher's PDF, also known as Version of record

\section{Please check the document version of this publication:}

- A submitted manuscript is the version of the article upon submission and before peer-review. There can be important differences between the submitted version and the official published version of record.

People interested in the research are advised to contact the author for the final version of the publication, or visit the DOI to the publisher's website.

- The final author version and the galley proof are versions of the publication after peer review.

- The final published version features the final layout of the paper including the volume, issue and page numbers.

Link to publication

\footnotetext{
General rights rights.

- You may freely distribute the URL identifying the publication in the public portal. please follow below link for the End User Agreement:

www.umlib.nl/taverne-license

Take down policy

If you believe that this document breaches copyright please contact us at:

repository@maastrichtuniversity.nl

providing details and we will investigate your claim.
}

Copyright and moral rights for the publications made accessible in the public portal are retained by the authors and/or other copyright owners and it is a condition of accessing publications that users recognise and abide by the legal requirements associated with these

- Users may download and print one copy of any publication from the public portal for the purpose of private study or research.

- You may not further distribute the material or use it for any profit-making activity or commercial gain

If the publication is distributed under the terms of Article $25 \mathrm{fa}$ of the Dutch Copyright Act, indicated by the "Taverne" license above, 


\title{
Supply and Demand, Allocation and Wage Inequality: An International Comparison
}

\author{
ROA-RM-2003/8E
}

Arnaud Dupuy and Lex Borghans

Research Centre for Education and the Labour Market

Faculty of Economics and Business Administration

Maastricht University

Maastricht, November 2003 
ISBN 90-5321-382-1

Sec03.177.doc 


\begin{abstract}
In this paper, we develop an allocation model of workers differentiated by their field of study to test whether international differences in the wage structure can be explained by differences in labor demand and supply in each country. The model explicitly takes into account the effects of supply an demand shifts on the allocation structure to disentangle country specific differences in the recruitment for one occupation from real supply-demand effects. Empirical results based on data for nine countries show that crosscountry differences in wage inequality explain at least $2 / 3$ of the differences in labor demand and supply.
\end{abstract}

Keywords: Allocation and Wage inequality

JEL Classifications: J21, J23, J31

\title{
Acknowledgement
}

The authors would like to thank Frank Cörvers, Andries de Grip, Philip Marey, David Margolis, Johan Muysken, Bas ter Weel and seminar participants at the Econometric Society European Meeting in Lausanne 2001, European Association of Labour Economists in Jyväskylä 2001 and Maastricht University for their comments.

\section{Authors}

Arnaud Dupuy

Research Centre for Education and the Labour Market

P.O. Box 616, NL-6200 MD Maastricht

Phone: (+31) 43 3883735, Fax: (+31) 433884914

E-mail: a.dupuy@roa.unimaas.nl

Internet : http://www.roa.unimaas.nl

Lex Borghans

Research Centre for Education and the Labour Market

P.O. Box 616, NL-6200 MD Maastricht

Phone: (+31) 43 3883444, Fax: (+31) 433884914

E-mail:1.borghans@,roa.unimaas.nl

Internet : $\underline{\text { http://www.roa.unimaas.nl }}$ 



\section{Introduction}

Relative wages of skill groups in the labor market can differ substantially between countries and between years. The main question is whether such differences in the wage structure reflect differences in supply and demand of the groups distinguished, or whether institutional factors like wage-setting, pay norms and minimum wage are the main cause of these differences in the wage structure. In the first case, a balanced composition of supply and demand would be a main determinant of labor productivity, while in the second case the institutional setting would be the key determinant to explain productivity differentials.

The major difficulty to investigate the effect of supply and demand on wages is that workers' skills have to be compared over time or between countries. The inter-temporal and international comparison of skills is problematic, since adequate standards to measure the level of skills do not exist. The challenge is to separate (i) the demand and supply explanation from (ii) the classification and the content of the study explanations. To contribute to the discussion we therefore investigate in this paper the effect of differences in supply and demand between different types of skills. By comparing types of skills (measured by field of study) we avoid the inherent problems of comparing skill levels between countries.

In the paper we develop an explicit model of occupational allocation and wage formation of skill groups. Since shifts in supply and demand should affect the allocation of an educational group in each occupation, we are able to disentangle supply and demand effects from country-specific differences in classification or the contents of a study. Disaggregation by occupation enables us to detect occupation-specific differences in the allocation that are not caused by supply-demand factors. The remaining supply-demand differential can be compared statistically with wage differentials in each country. Using data about the labor market position of graduates from nine countries, we estimate whether differences in the wage structure can be explained by differences in supply and demand. We find that the differences in the wage structure are consistent with a supply-demand explanation and show that with an elasticity of 2.14 , reducing wage differentials across countries by $100 \%$ reduces demand and supply differentials by at least $64 \%$.

The paper is related to literature about the growing wage inequality in the U.S. and literature about the differences in wage dispersion between the U.S. and countries in continental Europe (see Freeman and Katz (1995)), especially Germany. Katz and Murphy (1992) show that the increased wage inequality between skilled and unskilled workers in the U.S. can be explained from a supplydemand perspective if a constant exogenous growth in demand for skilled labor is assumed. Also Bound and Johnson (1992), Juhn et al. (1993), Levy and Murnane (1996), Machin and Van Reenen (1998) and Acemoglu (2002) argue that the rising wage inequality in the U.S. results from a skill biased technical change. Autor et al. (1998) and Krusell et al. (2000) demonstrate that computer 
investments could explain this increased demand for skilled labor. DiNardo et al. (1996), Lee (1999), Card and Lemieux (2001) and Card and DiNardo (2002) claim however that changes in wages do not reflect shifts in supply and demand. They argue that institutional changes rather than skill-biased technical change have caused the U.S. increase in wage inequality during the eighties. Especially the reduction in the real minimum wage and deunionisation are regarded as a main determinant for increased wage inequality.

Related to this discussion, Blau and Kahn (1996) investigate international differences in the wage inequality between skill groups. Based on years of schooling and experience they construct a measure of skill to compare supply between countries and conclude that the supply of skilled labor is positively related to the skilled-unskilled wage differential. Blau and Kahn therefore argue that the international pattern can not be explained by supply-demand differences and thus that institutional differences have to be responsible for the high income dispersion in the U.S. and the U.K. in comparison to European countries like Germany and France. Devroye and Freeman (2001) and Freeman and Schettkat (2001) raise questions about the validity of the skill measure used by Blau and Kahn, which is based on the assumption that each year of education and each year of experience lead to the same amount of skills in each country. International comparative studies in which students or workers in different countries take a similar test, like the Third International Mathematics and Science Study (TIMSS) ${ }^{1}$ or International Adult Literacy Survey (IALS) provide direct evidence on cross-country differences in the composition of skills by educational levels. These international tests focus however on a very specific set of skills, therefore maybe neglecting other skills that might be relevant for work. Using several techniques, especially based on the results of the IALS, Freeman and Schettkat show that the actual skill level of workers in Germany, especially with respect to the least skilled workers is much higher than was accounted for by Blau and Kahn. ${ }^{2}$ According to Freeman and Schettkat this less dispersed ability distribution of Germans can not explain the distribution of their wages completely, i.e. German workers in the lower segment of the labor market still earn relative more than their U.S. counterparts with equal ability. Leuven et al. (2004) use the IALS for a comparison of seven countries in which they also take into account the effects of supply and demand on the wage structure. They find, in contrast to Blau and Kahn (1996), the wage structures to be consistent with a supply demand explanation. The findings of Leuven et al. (2004) show that analyzes of the relationship between aggregate supply and demand and wages are very sensitive for the way in which skills are classified. ${ }^{3}$ Blau and Kahn (2001) indeed find that performance on cognitive

\footnotetext{
${ }^{1}$ See also Nickell and Bell (1996) and OECD (2001).

${ }^{2}$ American workers with less than 12 years of schooling score in average less than their counterparts elsewhere whereas with more than 16 years of schooling the picture is reversed.

${ }^{3}$ Devroye and Freeman (2001) show in this respect that immigrants seem to have low IALSscores compared to their wages, due to the relative importance of language ability in such
} 
tests plays a role in explaining greater US wage inequality but that higher labour market prices and residual inequality still play important roles. However, they also acknowledge that higher labor market prices in the US could be explained by either institutions or supply and demand. Our paper contributes to this discussion in two ways. First, the model we develop enables us to evaluate not only the sign but also the magnitude of the effects of supply and demand on the wage structure. Secondly, by taking advantage of the information contained in the occupational allocation of workers, our model is robust for the way in which skills are classified.

The allocation model developed in this paper is furthermore related to the literature on assignment models of heterogenous workers to heterogenous occupations developed in Roy (1951), Tinbergen (1956), Rosen (1978), Sattinger (1979) and Macdonald (1982). In our model we link wages to the supply of skills and to demand generated by the technology possibilities frontier of each economy. We distinguish between education and occupation and model the allocation of workers with different educational fields to the various occupations. The total labor supply by educational fields is exogenous in the model, while the allocation to occupations is assumed perfectly elastic to wage rates. The demand for workers with different educational fields in each occupation depends on the technology possibilities and is derived using a production function. The production technology is such that educational groups of workers are imperfect substitutes. The focus in this paper is therefore on between educational group wage inequality. If the skill contents of a study is comparable across countries, differences in supply and demand should correspond to differences in wage rates between countries. However, when differences in the contents of a study are observed, the optimal allocation of workers to the various occupations would differ across countries even at equivalent wage rates and supply and demand equilibrium. The allocation specification therefore enables us to disentangle supply and demand effects from country-specific differences in the employment of a group in a certain occupation either due to differences in classification or the contents of a study.

The structure of this paper is as follows. In the next section, the theoretical model is presented. Therein, we subsequently derive a method to identify the relationship between supply and demand and wages, allowing differences across countries in the allocation structure. The third section covers the sources and description of the data. In addition, we present measures of wage inequality for all countries in the data. The fourth section contains empirical results. Some final remarks and conclusions appear in section 5 .

tests. 


\section{Conceptual framework}

\section{Production function}

The economy of each country is assumed to produce one output-good denoted $H$. The price of this good is used as numeraire. In each occupation $i$ an intermediate good, denoted $H_{i}$ is produced with workers from different fields of study as input.

The production function with $n_{o}$ occupations and $n_{e}$ educational groups, takes the two-level Constant Elasticity of Substitution (CES) form (see Sato (1967)): ${ }^{4}$

$$
H=\min \left(\delta_{i} H_{i}\right)
$$

where $\delta_{i}$ is a technological parameter measuring the optimal proportion of output $i$ in output.

Assuming that the intermediate outputs are inelastic (Leontief production function at the occupational level), substitution on the goods market is impossible and all adjustments come from educational substitution within the various occupational groups. Note that allowing for substitution on the goods market is just a matter of decomposing the adjustments in the demand for workers into occupational and educational substitution. It would not affect substantially the magnitude of the adjusments in labour demand. ${ }^{5}$ Within each occupation, educational groups of workers are imperfect substitutes and occupational technology is defined by:

$$
H_{i}=\left(\sum_{j} a_{i j} L_{i j}^{\beta}\right)^{1 / \beta}
$$

where $a_{i j}$ is the productivity parameter of workers with education $j$ in occupation $i$ and satisfies $a_{i j}>0 \forall i, j$ and $\sum_{j} a_{i j}=1$. $\beta$ is a production technology parameter $^{6}$ and $\beta \leq 1$. $L_{i j}$ denotes the labor input with education $j$ in occupation $i$.

\footnotetext{
${ }^{4}$ For the sake of convenience, we skip the country index, i.e. $c$ on both the parameters and the variables of the model.

${ }^{5}$ We reproduced the analysis with the general 2-level CES production function specification and found similar results as those presented in this paper.

${ }^{6}$ The parameter of educational substitution elasticity within a single occupation equals $\sigma=$ $\frac{1}{1-\beta}$. Three noteworthy special cases are: (i) $\sigma \rightarrow 0$ (or $\beta \rightarrow-\infty$ ) when educational groups are to be used in fixed proportions within occupations (Leontief production function), (ii) $\sigma \rightarrow \infty$ (or $\beta \rightarrow 1$ ) when educational groups are perfect substitutes within occupations (linear production function) and (iii) $\sigma \rightarrow 1$ (or $\beta \rightarrow 0$ ) when the elasticity of substitution between educational groups within occupations is unity (Cobb-Douglas production function).
} 
The allocation is characterized by the distribution of workers by educational fields to the (various) occupational fields. The distribution of workers by educational background within each occupation need not to be concentrated on one educational group only. Rather, several educational fields may be fairly represented within an occupation (see for example Table 1). There is an inherent dispersion due to the heterogenous character of occupations and its impact on the assignment of tasks to educational groups of workers. Workers who find employment in the same occupation need not to perform exactly the same mix of tasks. Since educational fields differ in their skill content, workers with different educational backgrounds differ in their ability to perform the various tasks. Therefore, the optimal assignment of tasks to educational groups of workers leads to the presence of workers with different educational backgrounds in some (if not all) occupations. The optimal assignment of tasks changes as the wage rates by educational groups change through the supply and demand adjustment process. When comparing the allocation across countries, differences in supply and demand should correspond to differences in wage rates between countries. However, when differences in the contents of a study are observed, the optimal assignment of tasks to groups of workers would differ across countries generating differences in the allocation even at equivalent wage rates and supply and demand situations. $^{7}$ The difficulty to compare educational systems between countries makes it necessary to take into account such differences.

Assuming that both the labor and commodity markets are perfectly competitive, the demand for workers with different fields of study in the various occupations is derived by equating marginal products to the respective wage rates.

$$
\frac{\partial H}{\partial L_{i j}}=w_{j}
$$

However, since fields of study compete in more than one occupation, the Allen partial elasticities of substitution (see Allen 1938) between educational groups of workers need not to be equal to $\sigma$ nor to be constant between all pairs of educational groups of workers. $\sigma$ measures the partial elasticity of substitution between two educational groups of workers within an occupation. The Allen partial elasticities of substitution between two educational groups of workers equal:

$$
\begin{array}{r}
A_{j k}=\frac{\eta_{j k}}{s_{k}} \\
\text { with } \eta_{j k} \equiv \frac{\partial \ln L_{. j}}{\partial \ln w_{k}}=\sigma \sum_{i} s_{k, i} \frac{L_{i j}}{L_{. j}}
\end{array}
$$

where $\eta_{j k}$ is the corresponding cross-wage elasticity, $s_{k}$ the cost-share of educational group $k$ in total costs, $s_{k, i}=\frac{a_{i k}^{\sigma} w_{k}^{1-\sigma}}{\sum_{l} a_{i l}^{\sigma} w_{l}^{1-\sigma}}=\frac{w_{k} L_{i k}}{\sum_{l} w_{l} L_{i l}}$ the cost-share of workers with education $k$ in occupation $i$ and $L_{. j}=\sum_{i} L_{i j}$ the demand for workers with education $j$.

${ }^{7}$ Furthermore, differences in the classification of education might cause observed differences in the allocation of workers. 
The demand for workers with education $j$ in occupation $i$, expressed in logarithmic terms, reads as:

$$
\begin{aligned}
\ln L_{i j}= & \ln H-\ln \delta_{i}+\sigma \ln a_{i j}-\sigma \ln w_{j}+\sigma \ln P C_{i} \\
& \text { with } \\
P C_{i}= & \left(\sum_{k} a_{i j}^{\sigma} w_{j}^{1-\sigma}\right)^{\frac{1}{1-\sigma}}
\end{aligned}
$$

where $w_{j}$ stands for the wage of workers with education $j$. The function $P C_{i}$ represents the shadow price of producing one extra unit of intermediate output in occupation $i$ (the unit cost function).

From equation (4) we can derive changes in the demand for workers with education $j$ in occupation $i$ as a function of changes in wages, output and productivity parameters, i.e. $a_{i j}$. The demand equation in infinitesimal form equals:

$$
d \ln \frac{L_{i j}}{H}=\sum_{k} \frac{\partial \ln L_{i j}}{\partial \ln w_{k}} \times d \ln w_{k}+\sum_{k} \frac{\partial \ln L_{i j}}{\partial \ln a_{i k}} \times d \ln a_{i k}
$$

Using workers with education $l$ in occupation $g$ as the reference group, changes in the relative allocation of workers with different educational backgrounds and occupations read as:

$$
\begin{aligned}
d \ln \frac{L_{i j}}{L_{g l}}= & \sum_{k} \frac{\partial \ln L_{i j} / L_{g l}}{\partial \ln w_{k} / w_{l}} \times d \ln \frac{w_{k}}{w_{l}}+\sum_{k} \frac{\partial \ln L_{i j} / L_{g l}}{\partial \ln a_{i k} / a_{g l}} \times d \ln \frac{a_{i k}}{a_{g l}} \\
= & -\sigma \times d \ln \frac{w_{j}}{w_{l}}+\sigma \sum_{k}\left(s_{k, i}-s_{k, g}\right) \times d \ln \frac{w_{k}}{w_{l}} \\
& +\sigma \times d \ln \frac{a_{i j}}{a_{g l}}+\frac{\sigma^{2}}{1-\sigma} \sum_{k}\left(s_{k, i}-s_{k, g}\right) \times d \ln \frac{a_{i k}}{a_{g l}} \\
= & S D+A S
\end{aligned}
$$

where $s_{k, i}=\frac{a_{i k}^{\sigma} w_{k}^{1-\sigma}}{\sum_{l} a_{i l}^{\sigma} w_{l}^{1-\sigma}}=\frac{w_{k} L_{i k}}{\sum_{l} w_{l} L_{i l}}$ is the cost-share of workers with education $k$ in occupation $i$ and $L_{. j}=\sum_{i} L_{i j}$ the demand for workers with education $j$.

The change in the allocation of workers with education $j$ in occupation $i$ is decomposed into a supply and demand effect (denoted SD), initiated by changes in the relative supply of the various educational segments and, allocation structure effect (denoted AS) characterized by differences in the production function parameters $a_{i j}$. 
Changes in the demand for workers with the various educational background in the various occupations can be linked to exogenous changes in wages, due to shifts in the composition of supply, and the result of exogenous changes in the productivity parameters of the various types of workers.

In the context of cross-country analysis, exogenous changes in wage rates correspond to the distance between the relative wages observed in each country, and arbitrarily chosen new relative wages common to all countries. However, if the skill content of the graduates in the same field of study is not the same across countries, the relative productivity of workers in each field of study will vary across countries and so will wages. This will make it impossible to compare relative employment and wage equilibrium by educational groups of workers across countries even if the substitution process, linking differences in the relative supply of labor by fields of study with educational wage differentials, occurs freely. To illustrate the operation of the model we consider the differences in the relative wage of engineering graduates to business graduates in France and the UK. Great graphical simplification is achieved with only one occupation. Therefore in the following example we consider only workers in managerial occupation. Figure 1 shows the relative demand for and relative supply of graduates in that particular occupation. In France, the log relative wage observed is -0.1 and is accompanied by a log relative supply of -2.97 . Intuitively, an increase in the relative wage rate from -0.1 to $0.08\left(w_{u k}\right.$, relative wage in the UK, is 0.08$)$ induces substitution between both types of workers and reduces the relative demand from $L_{f r}$ to $L_{f r}^{\prime}$ through the operation $S D$ in equation (6). The fact that the new equilibrium point in France, i.e. point $B$ in Figure (1), does not correspond with the equilibrium point in the UK $\left(L_{f r}^{\prime}<-2.97<-1.03=L_{u k}\right)$, i.e. point $C$, implies differences in the productivity parameters between both countries. To match the UK equilibrium, the relative demand function in France has to shift from $L_{f r}^{D}$ to $L_{u k}^{D}$ through the operation of $A S$ in equation (6).

$<$ insert Figure 1>

\section{Isolating supply and demand from allocation structure effects}

Since institutions in some countries may choose to compress wages for social cohesion purposes, relative wages observed may, in those countries, not correspond to competitive wage rates. We therefore choose to correct for supply and demand differences across countries independently from observed wage rates. We do so by equalizing labor supply and demand by educational group and occupation in the various countries. In other words, for each country, we set the total supply of workers in each educational segment and the total demand for workers in each occupation to the nine-country average. After controlling for demand and supply differences between countries, the allocation of workers with different educational backgrounds to the various occupations in each country $c$, say $L_{i j, c}^{t}$, satisfies thereby the following conditions: 


$$
\left\{\begin{array}{l}
\sum_{i=1}^{n_{o}} L_{i j, c}^{t}=\overline{L_{. j}} \\
\sum_{j=1}^{n_{e}} L_{i j, c}^{t}=\overline{L_{i .}}
\end{array} \forall c\right.
$$

Equation (4) shows that changes in the allocation of workers as derived from the production function are bi-proportional and break down into an occupation specific $R_{i g}$ and an education specific $S_{j k}$ effect.

$$
\begin{aligned}
\ln \frac{L_{i j}^{t}}{L_{g k}^{t}} & =-\ln \frac{\delta_{i}}{\delta_{g}}+\sigma \ln \frac{a_{i j}}{a_{g k}}-\sigma \ln \frac{w_{j}^{t}}{w_{k}^{t}}+\sigma \ln \frac{P C_{i}\left(w^{t}\right)}{P C_{g}\left(w^{t}\right)} \\
\ln \frac{L_{i j}^{t}}{L_{g k}^{t}}-\ln \frac{L_{i j}^{0}}{L_{g k}^{0}} & =-\sigma\left(\ln \frac{w_{j}^{t}}{w_{k}^{t}}-\ln \frac{w_{j}^{0}}{w_{k}^{0}}\right)+\sigma\left(\ln \frac{P C_{i}\left(w^{t}\right)}{P C_{g}\left(w^{t}\right)}-\ln \frac{P C_{i}\left(w^{0}\right)}{P C_{g}\left(w^{0}\right)}\right) \\
\ln \frac{L_{i j}^{t}}{L_{g k}^{t}} & \Leftrightarrow \ln R_{i g}+\ln S_{j k}+\ln \frac{L_{i j}^{0}}{L_{g k}^{0}}
\end{aligned}
$$

Therefore, the new allocation of workers with education $j$ in occupation $i$ in each country, $L_{i j, c}^{t}$, can be derived by finding vectors $R_{. g}$ and $S_{. k}$ which satisfy the border conditions (same supply and demand vectors across countries) given the structure of allocation in country $c$, i.e. given the $a_{i j, c}$ of country $c$.

Equation (8) is equivalent to the RAS method. ${ }^{8}$ Using an iterative procedure in order to avoid approximation problems involved when inverting large matrices, ${ }^{9}$ we derive the demand and supply vectors $R_{i, c}$ and $S_{j, c}$ for each country such that the border conditions (equation 7 ) are satisfied, given the allocation observed in each country, $L_{i j, c}^{0}$.

This approach to derive changes in the allocation without taking wages explicitly into account is conceptually comparable to Tinbergen (1984). Tinbergen (1984) presents two structures related in our approach. The so-called Northwestcorner rule, $t$-method, that minimizes the total tension (in the case of diagonal matrix, when the demand vector equals the supply vector, i.e. 'educational equilibrium', only the main diagonal is non-empty) and, the independency solution met when the supply and demand probability distributions are independent. ${ }^{10}$

\footnotetext{
${ }^{8}$ See Stone and Brown (1964), Evans and Lindley (1973), Kadas and Klafzky (1976) and Van Eijs and Borghans (1996).

${ }^{9}$ For more details see Evans and Lindley (1973) and Van Eijs and Borghans (1996).

${ }^{10}$ Tinbergen notices that since the first solution concentrates all observations whereas the second solution spreads them evenly over the matrix, the actual allocation matrix may be some-
} 


\section{Allocation structure}

Because we imposed the border conditions to all countries, if all countries would have the same production function, i.e. the same $a_{i j}$, the allocation after correction for supply and demand differences should be equal for all nine countries. Hence, the differences between the nine-country average allocation and these constructed allocation matrices provides information about the differences in the production functions across countries. We use the distance between the logarithm of the relative average allocation and the logarithm of the relative new allocation to proxy the differences in the production function parameters across countries:

$$
\ln \frac{\overline{L_{i j}}}{\overline{L_{g k}}}-\ln \frac{L_{i j, c}^{t}}{L_{g k, c}^{t}}=\widehat{A S}_{i j, c}
$$

Obviously, if we observed one occupation only, then $\widehat{A S}$ would equal zero for all educational groups $j$ and all countries even if the true production functions ${ }^{11}$ are different across countries. In order to disentangle allocation structure differences across countries, at least two occupations are necessary. Intuitively, if one only knows that the relative employment of engineering graduates in France is twice the relative employment in the UK, one cannot conclude on whether the relative supply of engineering graduates in France is twice that of the UK or whether the engineering graduates in France are more productive in each occupation, compared to their UK counterparts. Our proxy therefore only picks up differences in occupation specific productivity, assuming that the relative average productivity of workers with two different educational backgrounds is about the same in each country.

\section{Supply and demand}

where in between. Our method minimizes the relative entropy, $E_{L^{0}}\left(L^{t}\right)=\sum_{i j} L_{i j, c}^{t} \ln \left(\frac{L_{i j, c}^{t}}{L_{i j, c}^{0}}\right)$, such that the new matrix $\left\{L_{i j, c}^{t}\right\}$ satisfies the border conditions conditional on the reference matrix $L^{0}$. The relative entropy reaches a global minimum, i.e. 0 , when the allocation $L_{i j, c}^{t}$ is equal to the allocation $L_{i j, c}^{0}$. Therefore, this method can be seen as a minimization of tension given relative scarcity of certain workers' characteristics (border vectors) and initial allocation. It is comparable to Tinbergen's $t$-method. However, in contrast with Tinbergen, our method uses a production function as underlying structure. Furthermore, when educational equilibrium is reached (supply vector equals demand vector) the resulting allocation would not necessarily lead to unimodal distribution of workers by education within each occupation and the new allocation satisfies the properties of equation (4).

${ }^{11}$ With one occupation, say $i$, even if the $a_{i j}$ parameters are different in the various countries, imposing the border conditions, $L_{i j c}^{t} \equiv L_{j, c}^{t}=\overline{L_{. j}} \equiv \overline{L_{i j}}$ implies $\widehat{A S}_{i j, c}=\ln \frac{\overline{L_{i j}}}{\overline{L_{i k}}}-\ln \frac{L_{i i c}^{t}}{L_{i k, c}^{t}}=0$. 
Bearing in mind the possible differences in production function parameters between countries, we confront observed relative wage rates to supply and demand across countries using the structural equation of the model, equation (6). The equation relates the allocation of workers to on the one hand the supply and demand, and on the other hand the structure of allocation. If wages reflect supply and demand they should explain allocation consistently after controlling for differences in production function. Comparing both the allocation structure and wages with the nine-country averages, we get:

$$
\begin{aligned}
\ln \frac{\overline{L_{i j}}}{\overline{L_{g l}}}-\ln \frac{L_{i j, c}^{0}}{L_{g l, c}^{0}=} & -\sigma\left(\ln \frac{w_{j}^{t}}{w_{l}^{t}}-\ln \frac{w_{j, c}^{0}}{w_{l, c}^{0}}\right)+ \\
& \sigma \sum_{k}\left(s_{k, i, c}-s_{k, g, c}\right)\left(\ln \frac{w_{j}^{t}}{w_{l}^{t}}-\ln \frac{w_{j, c}^{0}}{w_{l, c}^{0}}\right)+ \\
& \widehat{A S}{ }_{i j, c} \widehat{A S} \\
= & S D+\widehat{A S}
\end{aligned}
$$

\section{A supply and demand explanation}

The remaining question is how much of the observed differences in allocation across countries is due to observed differences in wage rates, allocation structures and other unobserved differences. To answer this question we decompose the allocation differences between countries in three factors. To that aim we introduce three quantities.

Quantity $A_{c}$ measures the distance between observed allocation and ninecountry average allocation. ${ }^{12}$

$$
A_{c}=\sum_{i j}\left|L_{i j, c}^{0}-\overline{L_{i j}}\right|
$$

Quantity $B_{c}$ measures the distance between country-specific allocation at equalized wage rates by education and nine-country average allocation.

\footnotetext{
${ }^{12}$ The unweighted absolute distances presented here may be driven by the distances observed where the allocation of workers is relatively large whereas the distances where the allocation of workers is relatively small are underestimated. We will therefore also compute absolute distances weighted by $\bar{L}_{i j}$, the world average allocation of workers to check the robustness of our results. The weighted absolute distances read as: $\widetilde{A}_{c}=\sum_{i j} \frac{\left|L_{i j, c}^{0}-\overline{L_{i j}}\right|}{\overline{L_{i j}}}, \widetilde{B}_{c}=\sum_{i j} \frac{\left|L_{i j, c}^{1}-\overline{L_{i j}}\right|}{\overline{L_{i j}}}$ and $\widetilde{C}_{c}=\sum_{i j} \frac{\left|\widehat{A S_{i j}}\right|}{\overline{L_{i j}}}$.
} 


$$
B_{c}=\sum_{i j}\left|L_{i j, c}^{1}-\overline{L_{i j}}\right|
$$

in which $L_{i j, c}^{1}$ represents the allocation associated with equal wages for all educational fields for each country:

$$
\begin{aligned}
\ln \frac{\overline{L_{i j}}}{\overline{L_{g l}}}-\ln \frac{L_{i j, c}^{1}}{L_{g l, c}^{1}}= & -\sigma\left(\ln 1-\ln \frac{w_{j, c}^{0}}{w_{l, c}^{0}}\right)+ \\
& \sigma \sum_{k}\left(s_{k, i, c}-s_{k, g, c}\right)\left(\ln 1-\ln \frac{w_{j, c}^{0}}{w_{l, c}^{0}}\right)+ \\
& \widehat{A S}_{i j, c}
\end{aligned}
$$

Rearranged and taking the exponential:

$$
\begin{aligned}
L_{i j, c}^{1} & =\operatorname{Exp}\left[\begin{array}{c}
\ln \frac{\overline{L_{i j}}}{L_{g l, c}^{1}}-\widehat{A S}_{i j, c}- \\
\sigma\left(\ln \frac{w_{j, c}^{0}}{w_{l, c}^{0}}-\ln 1\right)+ \\
\sigma \sum_{k}\left(s_{k, i, c}-s_{k, g, c}\right) \times\left(\ln \frac{w_{j, c}^{0}}{w_{l, c}^{0}}-\ln 1\right)
\end{array}\right] \\
L_{c}^{1}= & \sum_{i j} L_{i j, c}^{1}=1000
\end{aligned}
$$

$\ln 1$ indicates that the new allocation matrix $L_{i j, c}^{1}$ is associated to equal wage rates between educational groups of workers.

This measure of the distance between the allocation in different countries is corrected for country-specific wage-premia, that is those wages equilibrating country-specific supply and demand vectors ${ }^{13}$ but includes country-specific allocation structure and unobserved country-specific effect.

Quantity $C_{c}$ measures the distance between country-specific allocation given same supply and demand vectors across countries and nine-country average allocation matrix:

$$
C_{c}=\sum_{i j}\left|\widehat{A S_{i j}}\right|
$$

Therefore quantity $C_{c}$ measures the distance between the allocation structure of each country with an average structure/yardstick structure.

\footnotetext{
${ }^{13}$ This would imply equalized supply and demand vectors across countries if and only if the allocation structures were equal across countries.
} 


\section{Data}

The data we use for empirical analysis are taken from the "Careers after Higher Education European Research Survey" (CHEERS). Samples of graduates in higher education of the 1994/1995 academic year have been conducted 3 years after graduation (1998). The nine countries for which all necessary information were available are Italy, Spain, France, Austria, The Netherlands, The United Kingdom, Finland, Germany and Japan. The sample sizes are approximately 3,500 for each country and are representative of the target population defined along field of study, the type of degree/institution, gender and the region.

\section{The allocation of workers}

We make use of the information on the individuals' educational and occupational fields provided by the International Standard Classification of EDucation (ISCED, 3 digits) and the International Standard Classification of Occupation (ISCO, 3 digits) respectively. These two classifications distinguish categories, with respect to both the levels and the fields of education and occupation. The first digit of the two codes give the educational and job level, respectively, while the two last digits characterize the vocational fields. We re-code the 3-digits ISCED and ISCO into 7 educational fields and 11 occupational categories according to the classification reported in Table 7 of appendix A. Since most of the graduates end up in higher level occupations, and ISCO makes hardly any distinction between very different occupations at the first digit level, we refined the classification for high level jobs and take together lower level jobs. Based on this classification, the number of workers per education and occupation for the nine countries considered are computed.

The average number of workers per education and occupation in the nine countries is reported in Table 1 . The table shows that even though a large amount of workers are allocated to occupations for which their education is required, in each occupation the educational distribution of workers is fairly spread. The educational group with the largest frequency (Arts-Humanities field) accounts for $23 \%$ of the workers in Other-lower occupations. Health graduates account for up to $82 \%$ of the workers in Health occupations. Over all occupations, the number of workers having an education that differs from the educational field for which the largest frequency is observed adds up to about $48 \%$. This figure indicates a fair dispersion in the distribution of workers by education within occupations.

$<$ insert Table $1>$

Allocation turns out to be different between countries. To show this, we compute the average absolute distances between the allocation of workers with different education to the various occupations of each country and the ninecountry average allocation defined as: 


$$
\bar{A}_{c}=\frac{1}{7 \times 11} A_{c}=\frac{1}{7 \times 11} \sum_{i j}\left|L_{i j, c}^{0}-\overline{L_{i j}}\right|
$$

where $\bar{L}_{i j}$ is the nine-country average number of workers with education $j$ in occupation $i$ and $L_{i j, c}^{0}$ is the actual number of workers with education $j$ in occupation $i$ observed in country $c$. Both are expressed in promiles.

The absolute distances, reported in the bottom row of Table 8, indicate large differences in allocation matrices across countries. These differences may correspond with (i) cross-country differences in supply and demand situations, (ii) differences in the content of the various fields of study and/or (iii) differences across countries in the classifications of education and occupation. Though institutional factors might affect the level of employment, the relative allocation of workers with different education to the various occupations can reasonably be assumed unaffected by labour market institutional factors. The challenge is to separate (i) the demand and supply explanation from (ii) the classification and the content of the study explanations.

\section{The educational wage rates by country}

To derive the wage rates by educational category in each country, we run hourly earnings regressions independently for each country, including control for the effects of gender, age (quadratic form), job-tenure (quadratic form), hours weekly worked (log term), part-time, interaction of gender with age, job-tenure and part-time. Tenure is measured by means of workers' answers to the question: "In which year did you start your current job?" It therefore refers to an occupation-related-tenure rather than a firm-tenure. We excluded anyone earning less than 5 euro per hour or more than 150 euro per hour.

The following equation is estimated by OLS for each worker $p$ in country $c$ :

$$
\ln W_{p, c}=\gamma_{c}+G_{c}^{\prime} X_{p c}+\sum_{j} \alpha_{j, c} E_{j}+e_{p, c}
$$

The variable $\ln W$ is the log of hourly earnings; $X_{p c}$ is a vector of explanatory variables including workers characteristics, ${ }^{14} E_{j}$ are dummies for educational fields. The estimates for $\alpha_{j, c}$ as reported in Table 8 of appendix B, can be regarded as educational wage-premia for each country.

\footnotetext{
${ }^{14}$ Age and its square, tenure and its square, a dummy variable for part-time work (less than 36 hours per week), gender and its interaction with age, tenure and part-time, and the log of weekly hours worked.
} 


\section{Wage inequality across countries}

In several studies, wage inequality is found very different across countries with a larger wage inequality in the US and the UK than in continental Europe and Japan. ${ }^{15}$ In order to evaluate the extent to which this stylised fact is reflected in our data on higher educated workers we compute some measures of wage inequality. ${ }^{16}$

First we derive from the estimation of equation (12) the total variance and the within and between educational categories variance in log hourly earnings. The total variance as well as the variance within and between educational categories in log hourly earnings are given by:

$$
\begin{aligned}
\text { Within }_{c} & =\frac{1}{L_{c}} \sum_{j} L_{j, c} \times \sum_{p, E_{j}=1}\left(\ln W_{p, c}-\widehat{\ln W}_{p, c}\right)^{2} \\
\text { Between }_{c} & =\frac{1}{L_{c}} \sum_{j} L_{j, c} \times \sum_{p, E_{j}=1}\left(\widehat{\ln W}_{p, c}-\widehat{\ln W}_{c}\right)^{2} \\
\text { Total }_{c} & =\frac{1}{L_{c}} \sum_{p}\left(\ln W_{p, c}-\widehat{\ln W}_{c}\right)^{2}
\end{aligned}
$$

where $L_{j, c}$ is the number of workers with education $j$ in country $c, L_{c}$ is the number of workers in country $c, \widehat{\ln W}_{p, c}$ is the estimated log-earnings for workers $p$ in country $c$ and $\overline{\ln }_{c}$ is the average log-earnings in country $c$.

We complete the analysis of wage inequality by computing for each worker in each country, $Y_{p, c}$, the male, 40 hours per week, 30 years old, 2.8 years of tenure, etc. ${ }^{17}$... equivalent hourly earnings using equation (12) as follows:

$$
\begin{aligned}
Y_{p, c} & =\ln W_{p, c}-\gamma_{c}-G_{c}^{\prime}\left(X_{p, c}-\bar{X}\right) \\
& =\sum_{j} \alpha_{j, c} E_{j}+G_{c}^{\prime} \bar{X}+e_{p, c}
\end{aligned}
$$

For each country, the standard-deviation and the 10, 50 and 90 percentiles of the corrected hourly earnings distribution are computed. The variance decomposition of the hourly earnings distribution as well as the 50-10, 90-50 and 90-10 percentiles gaps in the corrected hourly earnings distribution are reported

\footnotetext{
${ }^{15}$ See for instance Blau and Kahn (1996), Leuven et al. (2004), Devroye and Freeman (2001) and Freeman and Schettkat (2001).

${ }^{16}$ Notice that our measure of between educational fields wage inequality is part of the within educational levels wage inequality measured in most empirical analyses.

${ }^{17}$ The world-wide average age and tenure are 30 years of age and 2.8 years of tenure.
} 
for each country in Table 2. Whereas most studies that differentiate workers by their educational level find a significantly higher inequality in the UK, we find no such evidence among workers with the same educational level. The total variance in hourly earnings and the variance within educational groups in the UK is of the same magnitude as that of France, Germany and to some extent Japan. These results are corroborated by those derived from the distribution of the corrected hourly earnings. The standard deviation of the distribution of the corrected hourly earnings for the UK is indeed roughly the same as that for France and Germany. Though, the 90-10 gap in earnings differential in the UK lies above that of Germany, we find no differences between the UK and France and Austria and even a slightly larger 90-10 gap for Italy. This result is consistent with the view that the large wage differentials in the UK reflect a wide distribution of skill levels among the workforce.

$<$ insert Table $2>$

\section{Empirical Results}

The substitution elasticity and relative equilibrium wages

From the model we derive four nested specifications. ${ }^{18}$ First, assuming that all countries have the same allocation structure, i.e. there are no differences in the production functions, the model reduces to Specification (I).

$$
\begin{aligned}
\ln \frac{\overline{L_{i j}}}{\overline{L_{g l}}}-\ln \frac{L_{i j, c}^{0}}{L_{g l, c}^{0}}= & -\sigma\left(\ln \frac{w_{j}^{t}}{w_{l}^{t}}-\ln \frac{w_{j, c}^{0}}{w_{l, c}^{0}}\right)+ \\
& \sigma \sum_{k}\left(s_{k, i, c}-s_{k, g, c}\right)\left(\ln \frac{w_{j}^{t}}{w_{l}^{t}}-\ln \frac{w_{j, c}^{0}}{w_{l, c}^{0}}\right)+\varepsilon_{i j, c} \\
= & S D
\end{aligned}
$$

In the second Specification (II), we model the allocation changes against differences in the allocation structure only.

$$
\ln \frac{\overline{L_{i j}}}{\overline{L_{g l}}}-\ln \frac{L_{i j, c}^{0}}{L_{g l, c}^{0}}=\gamma \widehat{A S}_{i j, c}+\varepsilon_{i j, c}
$$

\footnotetext{
${ }^{18} \mathrm{We}$ estimate the demand equations with wage on the right-hand side and employment on the left-hand for statistical reasons. Indeed, since employment is differentiated by education and occupation whereas wages are differentiated by education only, there is more variance in the employment variable than there is in the wage variable.
} 
In the third and fourth specifications, both changes in wages and differences in allocation structure are nested. Specification (III) corresponds to equation (10) where we replace the true allocation structure effect by its proxy $\widehat{A S}$.

$$
\begin{aligned}
\ln \frac{\overline{L_{i j}}}{\overline{L_{g l}}}-\ln \frac{L_{i j, c}^{0}}{L_{g l, c}^{0}=} & -\sigma\left(\ln \frac{w_{j}^{t}}{w_{l}^{t}}-\ln \frac{w_{j, c}^{0}}{w_{l, c}^{0}}\right)+ \\
& \sigma \sum_{k}\left(s_{k, i, c}-s_{k, g, c}\right)\left(\ln \frac{w_{j}^{t}}{w_{l}^{t}}-\ln \frac{w_{j, c}^{0}}{w_{l, c}^{0}}\right)+ \\
& \widehat{A S}_{i j, c}+\varepsilon_{i j, c}
\end{aligned}
$$

To check the robustness of the $A S$-proxy in Specification (IV) we actually estimate the coefficient of the allocation structure effect rather than assuming unity. Comparing the results of both specifications enables us to evaluate the impact of using the proxy $\widehat{A S}$ for the real allocation structure effect.

$$
\begin{aligned}
\ln \frac{\overline{L_{i j}}}{\overline{L_{g l}}}-\ln \frac{L_{i j, c}^{0}}{L_{g l, c}^{0}=} & -\sigma\left(\ln \frac{w_{j}^{t}}{w_{l}^{t}}-\ln \frac{w_{j, c}^{0}}{w_{l, c}^{0}}\right)+ \\
& \sigma \sum_{k}\left(s_{k, i, c}-s_{k, g, c}\right)\left(\ln \frac{w_{j}^{t}}{w_{l}^{t}}-\ln \frac{w_{j, c}^{0}}{w_{l, c}^{0}}\right)+ \\
& \gamma \widehat{A S}_{i j, c}+\varepsilon_{i j, c}
\end{aligned}
$$

We estimate specifications (I), (III) and (IV) by nonlinear least squares method and specification (II) by ordinary least squares. The results of the estimations are reported in Table 3 . When no control for differences in the allocation structure are included, changes in wages across countries, through a production function specification, explain little of the changes in allocation as indicated by the very low adjusted $R^{2}$ of specification (I). Though of a realistic magnitude, ${ }^{19}$ the estimate of the substitution elasticity parameter obtained via specification (I) is found insignificant.

$<$ insert Table $3>$

The results derived by estimating the model with specification (II) indicate that differences in allocation across countries are to a large extent due to differences in allocation structure. The adjusted $R^{2}$ increases drastically compared to

\footnotetext{
${ }^{19}$ See Hamermesh $(1992 ; 1993)$ (Hamermesh 1992) for an exhaustive survey of empirical estimates of labor-labor substitution elasticities. Hamermesh 's law, based on empirical regularities, indicates that labor-labor substitution elasticities lie around 1.4.
} 
that of specification (I) indicating a large explicative power of allocation structure differences on differences in allocation observed across countries.

Therefore in specification (III) and (IV) we account for the allocation structure differences when estimating the production function. The results show that once we control for the differences in allocation structures, we are able to explain a significantly larger part of the variance in allocation, ${ }^{20}$ and the elasticity of substitution parameter becomes significant (at 1\%).

The estimated substitution elasticity within occupations equals 2.14. Table 4 reports the Allen elasticities of substitution between all pairs of educational groups to illustrate the substitution possibilities between educational groups. The elasticities have been evaluated for the nine-country average allocation and equal wage rates between educational groups. The own-wage elasticities indicate that countries usually have more difficulties to adjust changes in relative wages of Health graduates $(-0.98)$ while they can more easily adjust changes in the wage rate of Social sciences graduates $(-1.74) .{ }^{21}$

<insert Table $4>$

\section{A supply and demand explanation of wage differentials across countries}

The remaining question is how much of the observed differences in allocation across countries is due to observed differences in wage rates, allocation structures and other unobserved differences. To answer this question we use the estimates of specification (III) and decompose the allocation differences between countries into quantity $A_{c}$ which measures the distance between observed allocation and nine-country average allocation, quantity $B_{c}$ which measures the distance between country-specific allocation at equalized wage rates by education and nine-country average allocation and quantity $C_{c}$ which measures the distance between countryspecific allocation given same supply and demand vectors across countries and nine-country average allocation matrix.

Table 5 reports the results for the unweighted distances. First, the total actual differences in allocation reduces from 5377 to 3680 when wage differentials across countries are eliminated. This result implies that the between-educational-group wage differentials across countries account for $31.6 \%$ of the observed allocation

\footnotetext{
${ }^{20}$ A F-test reveals that Specification (IV) also fits the data significantly better than Specification (II), at the $1 \%$ level.

${ }^{21}$ All elasticities lie in the range of empirical regularities observed in Hamermesh (1992) and (1993) and Hamermesh and Grant (1979). Though obtained in a context of cross-country analysis of wage differentials, the magnitude of our elasticities is comparable to the magnitude of elasticities obtained from time-series analyses. Bound and Johnson (1992) find a parameter of substitution elasticity of 1.75 between skill-groups within sectors once accounting for skilled-biased technological change, Katz and Murphy (1992)'s estimate implies an elasticity of substitution between college and high school labor of 1.41. In our data, the largest elasticity of substitution is found between Engineering graduates and graduates in Natural Sciences which equals 3.07 while the lowest elasticity of substitution is found between Engineering graduates and graduates from Law school (0.78).
} 
differences as indicated in the second a last row of the table. However, the differences in allocation structure already account for roughly $51 \%(2721 / 5377=.506)$ of the differences in observed allocation across countries. The last row of the table indicates that, once we substrate the allocation structure differences across countries, the between-educational-group wage differentials across countries account for $63.9 \%$ of the observed allocation differences. To check the robustness of these results, we computed the weighted the absolute distances. The weights are the world wide average number of workers with education $j$ in occupation $i$ to control for the possibility that the absolute distances are driven by a few distances observed where the allocation of workers to occupation is large. The results, reported in Table 6 , indicate that wage differentials across countries account for 93.3\% of the observed weighted allocation differences

These results imply that after correcting for differences in the production function between countries at least $2 / 3$ of the differences in allocation can be explained by wage differentials while at most $1 / 3$ remains unexplained and might be due to institutional factors.

$<$ insert Table $5>$

$<$ insert Table $6>$

\section{Conclusion}

In this paper, we develop an explicit model of occupational allocation and wage formation of skill groups to test alternative hypotheses of wage differentials across countries. The main question is whether differences in the wage structure by skill groups across countries reflect differences in supply and demand of the groups distinguished or whether institutional factors like wage-setting, pay norms and minimum wage are the main cause for these differences in wage structure.

Since shifts in supply and demand should affect the allocation of a group in each occupation, our allocation model enables to disentangle supply and demand effects from country-specific differences in the employment of a group in a certain occupation either due to differences in education/occupation classifications or the contents of a study. Isolating occupation-specific differences in the allocation that are not caused by supply-demand factors, the remaining supply-demand differential is compared statistically with wage differentials in each country. Empirical results show that these allocation structure differences account for $50 \%$ of allocation differences across countries. Once correcting for these differences in allocation structure, we find that with a labor-labor substitution elasticity parameter of 2.14, the shifts in demand and supply account for at least $64 \%$ of the allocation differences between countries. Reducing wage differentials across countries by $100 \%$ reduces allocation differences by at least $64 \%$. The remaining $36 \%$ can be imputed to unobserved factors, that may be related to labour market institutional factors like wage-setting, pay norms and minimum wage. 


\section{References}

Acemoglu, D. (2002): "Technical Change, Inequality and the Labor Market," Journal of Economic Literature, 40(1), 7-72.

Allen, R. (1938): Mathematical Analysis for Economists. London: Macmillan.

Autor, D., F. Katz, And A. Krueger (1998): "Computing Inequality: Have Computers Changed the Labor Market?," Quarterly Journal of Economics, 113(4), 1169-213.

Blau, F., and L. Kahn (1996): "International Differences in Male Wage Inequality: Institutions Versus Market Forces," Journal of Political Economy, 104(4), 791-837.

(2001): "Do Cognitive Test Scores Explain Higher US Wage Inequality?," NBER Working Paper, 8210.

Bound, J., And G. Johnson (1992): "Changes in the Structure of Wages During the 1980's: An Evaluation of Alternative Explanations," American Economic Review, 82(3), 371-92.

Card, D., and J. DiNardo (2002): "Skill Biased Technological Change and Rising Wage Inequality: Some Problems and Puzzles," NBER Working Paper, 8769 .

Card, D., and T. Lemieux (2001): "Can Falling Supply Explain the Rising Return to College for Younger Men? A Cohort-Based Analysis," Quarterly Journal of Economics, 116(2), 705-46.

Devroye, D., and R. Freeman (2001): "Does Inequality in Skills Explain Inequality of Earnings Across Countries?," NBER working paper, 8140.

DiNardo, J., N. Fortin, and T. Lemieux (1996): "Labor Market Institutions and the Distribution of Wages, 1979-1992: A Semi-Parametric Approach," Econometrica, 64(5), 1001-44.

Evans, G., and R. Lindley (1973): "The Use of RAS and Related Models in Manpower Forecasting," Economics of Planning, 13(1-2), 53-73.

Freeman, R., and L. Katz (1995): Differences and Changes in Wage Structureschap. 1, pp. 1-22. Chicago, The University of Chicago Press.

Freeman, R., and R. Schettkat (2001): "Skill Compression, Wage Differentials, and Employment: Germany vs The U.S.," Oxford Economic Papers, $53(3), 582-603$. 
Hamermesh, D. (1992): "The Demand for Labor in the Long Run.," in Handbook of Labor Economics., ed. by O. Ashenfelter, and R. Layard, pp. 429-71. Amsterdam: North Holland.

Press. (1993): Labor Demand. Princeton, New Jersey: Princeton University

Hamermesh, D., and J. Grant (1979): "Econometric Studies of Labor-Labor Substitution and their Implications for Policy," Journal of Human Resources, $14(4), 518-42$.

Juhn, C., K. Murphy, And B. Pierce (1993): "Wage Inequality and the Rise in Returns to Skill," Journal of Political Economy, 101(3), 410-42.

Kadas, S., And E. KlafzKy (1976): "Estimation of the Parameters in the Gravity Model for Trip Distribution: A New Method and Solution Algorithm," Regional Science and Urban Economics, 6(4), 439-57.

Katz, L., And K. Murphy (1992): "Changes in Relative Wages, 1963-1987: Supply and Demand Factors," Quarterly Journal of Economics, 107(1), 35-78.

Krusell, P., L. Ohanian, V. Ríos-Rull, and G. Violante (2000): "Capital-Skill Complementarity and Inequality: A Macroeconomic Analysis," Econometrica, 68(5), 1029-53.

Leuven, E., H. Oosterbeek, and H. Van Ophem (2004): "Explaining International Differences in Male Wage Inequality by Differences in Demand and Supply of Skill," Economic Journal, forthcoming.

Levy, F., And R. Murnane (1996): "With What Skills are Computers Complements?," American Economic Review, 86(2), 258-62.

MacDonald, G. (1982): "A Market Equilibrium Theory of Job Assignment and Sequential Accumulation of Information," American Economic Review, 72(5), $1038-55$.

Machin, S., And J. Van Reenen (1998): "Technology and Changes in Skill Structure: Evidence from Seven OECD Countries," Quarterly Journal of Economics, 113(4), 1215-44.

Nickell, S., And B. Bell (1996): "Changes in the Distribution of Wages and Unemployment in OECD Countries," American Economic Review, Papers and Proceedings, 86(2), 302-8.

OECD (2001): Education at a Glance: OECD Indicators. Paris: OECD publications. 
Rosen, S. (1978): "Substitution and the Division of Labor," Economica, 45, $235-50$.

Roy, A. (1951): "Some Thoughts on the Distribution of Earnings," Oxford Economic Papers, 3(1), 135-46.

SAto, K. (1967): "A Two-Level CES Production Function," Review of Economic Studies, 34, 201-18.

SATtinger, M. (1979): "Comparative Advantage and the Distributions of Earnings and Abilities," Econometrica, 43(3), 455-68.

Stone, R., And A. Brown (1964): A Computable Model of Economic Growth, vol. 1 of the series "A Programme for Growth". London: Chapman and Hall.

Tinbergen, J. (1956): "On the Theory of Income Distribution," Weltwirtschaftliches Archiv, 77(1), 156-75.

(1984): "Allocation of Workers over Jobs," De Economist, 132(1), 23-9.

Van EiJs, P., and L. Borghans (1996): "The Use of RAS in Manpower Forecasting: A Microeconomic Approach," Economic Modelling, 13, 257-87. 


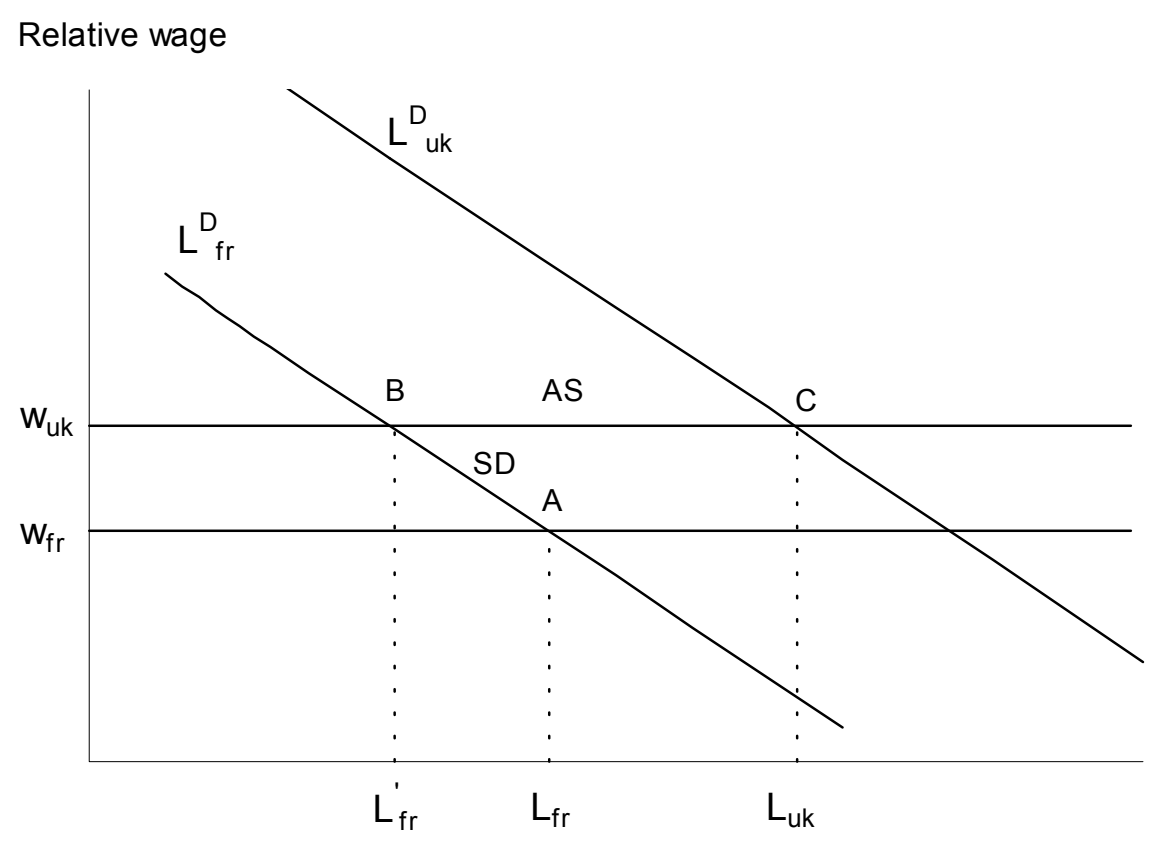

Figure 1: An increase in the relative wage in France induces substitution between the two groups of workers and movements on the demand curve from point A to point B. The vector $\mathrm{AB}$ corresponds to the supply and demand effect (SD) captured in equation 9. The relative demand in France however does not match the relative demand in the UK though the relative wages are equal. The distance between the relative demand in France and the relative demand in the UK corresponds to differences in productivity parameters. The vector BC corresponds to the allocation structure effect (AS) captured in equation (9). 
Table 1: Average number of workers by education and occupation expressed in the nine countries in promile.

\begin{tabular}{|c|c|c|c|c|c|c|c|c|}
\hline \multirow[b]{2}{*}{ Occupation } & \multicolumn{5}{|c|}{ Education $^{a}$} & \multirow[b]{2}{*}{ Engineer } & \multirow[b]{2}{*}{ Health } & \multirow[b]{2}{*}{ total } \\
\hline & Arts-Hum & Soci-Scie & Business & Law & Natur-scie & & & \\
\hline Arts-Hum & 17 & 6 & 9 & 2 & 2 & 2 & 1 & 39 \\
\hline Soci-Scie & 15 & 24 & 15 & 2 & 1 & 2 & 7 & 66 \\
\hline Business & 14 & 18 & 60 & 11 & 8 & 10 & 2 & 123 \\
\hline Legal & 3 & 2 & 1 & 36 & 1 & 1 & 1 & 45 \\
\hline Sciences & 6 & 5 & 11 & 2 & 59 & 44 & 7 & 134 \\
\hline Engineering & 3 & 2 & 7 & 1 & 14 & 92 & 1 & 120 \\
\hline Health & 3 & 2 & 1 & 1 & 2 & 5 & 64 & 78 \\
\hline Managers & 19 & 16 & 39 & 5 & 7 & 17 & 6 & 109 \\
\hline Teaching & 89 & 12 & 10 & 2 & 21 & 11 & 5 & 150 \\
\hline Clerks & 22 & 17 & 24 & 10 & 3 & 5 & 3 & 84 \\
\hline Other-lower & 12 & 10 & 11 & 4 & 4 & 8 & 3 & 52 \\
\hline total & 203 & 114 & 188 & 76 & 122 & 197 & 100 & 1000 \\
\hline
\end{tabular}

${ }^{a}$ For each occupation, the educational group with the largest frequency is represented in bold. 
Table 2: Variance decomposition of hourly earnings for each country.

\begin{tabular}{l|ccccccccc}
\hline \hline & $\mathrm{It}$ & $\mathrm{Sp}$ & $\mathrm{Fr}$ & $\mathrm{Au}$ & $\mathrm{Nl}$ & $\mathrm{UK}$ & $\mathrm{Fi}$ & $\mathrm{Ge}$ & $\mathrm{Jp}$ \\
\hline $\ln W_{p, c}$ & & & & & & & & & \\
Variance decomposition & & & & & & & & & \\
Between $_{c}(\times 10)$ & .10 & .07 & .16 & .08 & .03 & .03 & .07 & .05 & .03 \\
Within $_{c}$ & .14 & .16 & .11 & .12 & .05 & .12 & .08 & .10 & .08 \\
Total $_{c}$ & .19 & .19 & .15 & .18 & .09 & .15 & .10 & .15 & .11 \\
\hline$Y_{p, c}$ & & & & & & & & & \\
Wage Inequality $_{50-10}$ & & & & & & & & & \\
$90-50$ & .50 & .59 & .50 & .45 & .27 & .44 & .32 & .42 & .41 \\
$90-10$ & .38 & .49 & .36 & .41 & .28 & .42 & .34 & .33 & .29 \\
Stdv & .88 & 1.08 & .86 & .86 & .55 & .86 & .66 & .75 & .70 \\
\hline \hline
\end{tabular}

The variance of hourly earnings is decomposed into between, within and total variance as obtained from estimation of separate regressions of equation 12 for each country.

The standard deviation and the 50-10, 90-50 and 90-10 percentile gaps of the distribution of corrected hourly earnings as obtained from equation 13. 
Table 3: The relationship between allocation, wages and the allocation structure.

\begin{tabular}{|c|c|c|c|c|c|c|c|c|}
\hline Specification & (I) & & (II) & & (III) & & (IV) & \\
\hline \multicolumn{9}{|l|}{ Education } \\
\hline Arts-Hum & & - & & & & - & & - \\
\hline Soci-Scie & .070 & $(.221)$ & & & .015 & $(.090)$ & .013 & $(.090)$ \\
\hline Business & -.177 & $(.312)$ & & & .064 & $(.091)$ & .069 & $(.091)$ \\
\hline Law & -.526 & $(.470)$ & & & -.053 & $(.094)$ & -.042 & $(.094)$ \\
\hline Natur-Scie & -.105 & $(.271)$ & & & .102 & $(.089)$ & .107 & $(.090)$ \\
\hline Engineer & -.229 & $(.343)$ & & & .151 & $(.089)$ & .160 & $(.090)$ \\
\hline Health & -.962 & $(.765)$ & & & -.109 & $(.102)$ & -.089 & $(.100)$ \\
\hline Const & .252 & $(.389)$ & .077 & $(.053)$ & .002 & $(.146)$ & .007 & $(.146)$ \\
\hline$\sigma$ & 2.362 & $(1.695)$ & & & 2.143 & $(.623)^{* *}$ & 2.138 & $(.623)^{* *}$ \\
\hline Control $\widehat{A S}$ & No & & Yes & & Yes & & Yes & \\
\hline$\gamma$ & - & & 1.026 & $(.015)^{* *}$ & - & & 1.020 & $(.016)^{* *}$ \\
\hline$T$ & 684 & & 684 & & 684 & & & 684 \\
\hline $\mathrm{df}$ & 8 & & 2 & & 8 & & & 9 \\
\hline$R_{\text {adj }}^{2}$ & 0.097 & & 0.876 & & 0.878 & & & 0.878 \\
\hline
\end{tabular}

* significant at $10 \%$

** significant at 5\% 
Table 4: Own-wage elasticities and Allen partial elasticities of substitution evaluated for the world-wide allocation and equal wages across educational fields.

\begin{tabular}{llrrrrrr}
\hline \hline \multicolumn{2}{l}{ Educational Fields } & \multicolumn{5}{c}{ Quantity of: } \\
With respect & Arts- & Social & Busin & Law & Natur- & Engin & Health \\
to wage of: & Huma & Siences & & & Scienc & & \\
\hline Arts-Humanities & -1.32 & 2.53 & 2.05 & 1.49 & 1.78 & 1.05 & 1.12 \\
Social-Sciences & & -1.74 & 2.97 & 1.99 & 1.30 & 1.12 & 1.39 \\
Business & & & -1.46 & 1.94 & 1.49 & 1.43 & 0.94 \\
Law & & & -1.25 & 0.91 & 0.78 & 0.88 \\
Natural-Sciences & & & & & -1.58 & 3.07 & 1.15 \\
Engineer & & & & & & -1.15 & 1.04 \\
Health & & & & & & & -0.98 \\
\hline Shares & .203 & .114 & .188 & .076 & .122 & .197 & .100 \\
\hline \hline
\end{tabular}


Table 5: Decomposition of international differences in allocation into supply and demand effects and allocation structure effects.

\begin{tabular}{l|ccccccccc|c}
\hline \hline $\begin{array}{l}\text { Countries } \\
\text { Gap in allocation: }\end{array}$ & It & Sp & Fr & Au & Nl & UK & Fi & Jp & Ge & Tot \\
\hline $\begin{array}{l}\text { Observed } \\
\mathrm{A}_{c}\end{array}$ & 551 & 555 & 633 & 658 & 643 & 500 & 525 & 814 & 498 & 5377 \\
$\begin{array}{l}\text { Control for } S D \\
\mathrm{~B}_{c}\end{array}$ & 416 & 406 & 437 & 470 & 465 & 345 & 375 & 396 & 370 & 3680 \\
$\begin{array}{l}\text { Structure } \\
\mathrm{C}_{c}\end{array}$ & & & & & & & & & & \\
& 299 & 314 & 327 & 380 & 391 & 220 & 262 & 277 & 251 & 2721 \\
\hline $\begin{array}{l}\text { Control for } A S \\
\mathrm{~A}_{c}^{\prime}=\mathrm{A}_{c}-\mathrm{C}_{c}\end{array}$ & 252 & 241 & 306 & 278 & 252 & 280 & 263 & 537 & 247 & 2656 \\
$\begin{array}{l}\text { Control for } \\
\text { SD and } A S\end{array}$ & & & & & & & & & & \\
$\mathrm{~B}_{c}^{\prime}=\mathrm{B}_{c}-\mathrm{C}_{c}$ & 117 & 92 & 110 & 90 & 74 & 125 & 113 & 119 & 119 & 959 \\
& & & & & & & & & & \\
\hline $\begin{array}{l}\text { \% Change in } \\
\text { Allocation }\end{array}$ & & & & & & & & & & \\
$\begin{array}{l}\text { No control for } A S \\
\text { Control for } A S\end{array}$ & 24.4 & 26.8 & 31.0 & 28.6 & 27.8 & 31.0 & 28.6 & 51.3 & 25.7 & 31.6 \\
\hline \hline
\end{tabular}


Table 6: Decomposition of international differences in allocation into supply and demand effects and allocation structure effects, using weighted absolute distances

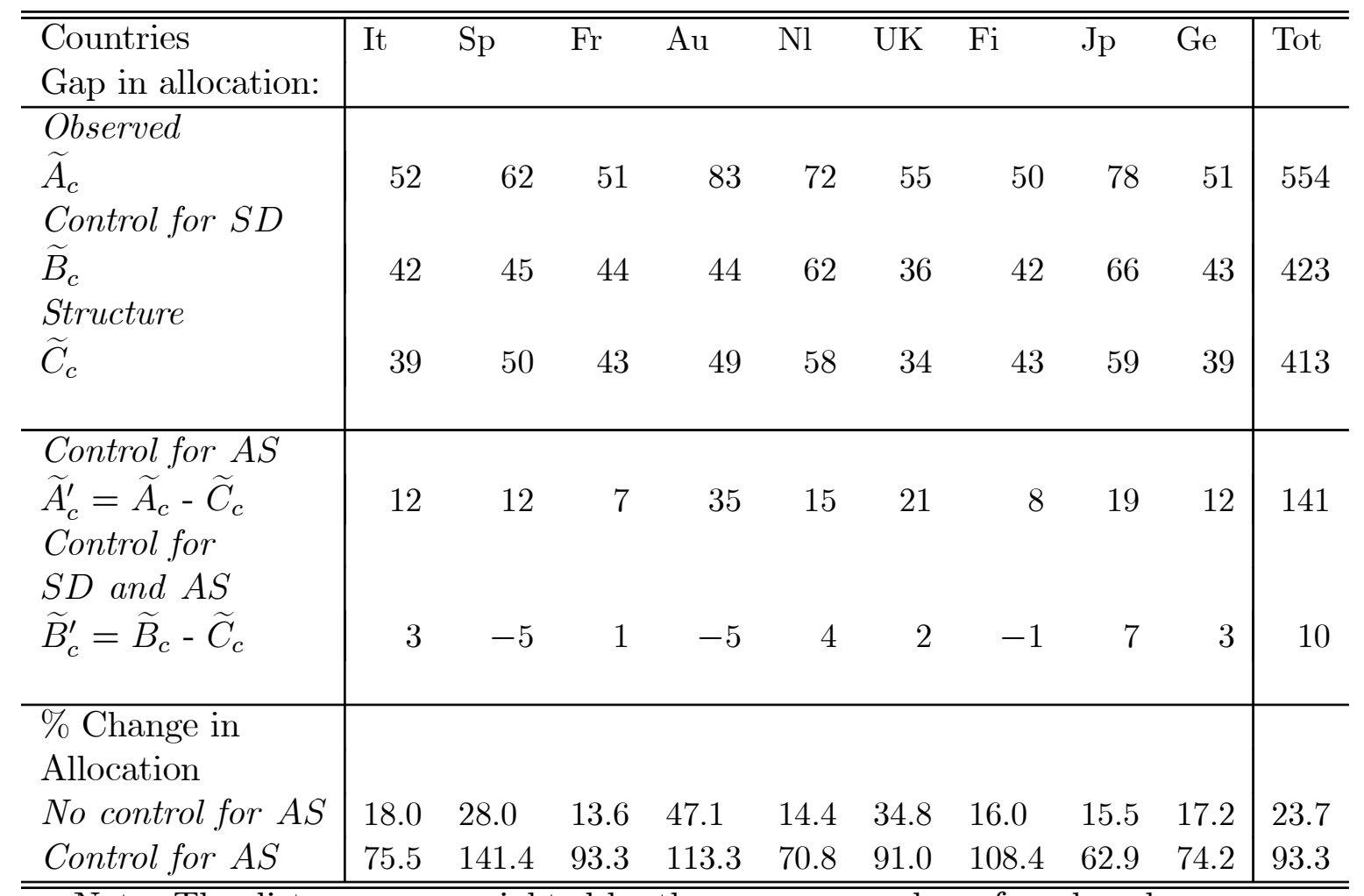

Note: The distances are weighted by the average number of workers by education and occupation 


\section{Appendix A: Table 1 presents the cross-classification of workers' educational backgrounds and the various jobs.}

Table 7: Classification of educational fields and occupational fields ("required education").

\begin{tabular}{l|l}
\hline \hline Educational fields & ISCED $^{22}$ codes (3 digits) \\
\hline & $14,20,21,22$ \\
Arts-Humanities & $30-32$ \\
Social-Sciences & $34,80-81,84,86$ \\
Business & 38 \\
Law & $40-48$ \\
Natural-Sciences & $50-64,85$ \\
Engineer & $72-76$ \\
Health & \\
& ISCO 23 codes (3 digits) \\
\hline Occupations & \\
\hline & $100-131$ \\
Legislators-Managers & $200-213,220-221,300-312,314-321$ \\
Natural-Sciences & 214 \\
Engineering & $222-225,313,322-323$ \\
Health & $230-235,331-334$ \\
Teaching & $240-241,341-343$ \\
Business & $242,344-345$ \\
Legal & $243-244,346$ \\
Social-Sciences & $245-271,347-349$ \\
Arts-Humanities & $400-490$ \\
Clerks & $>499$ \\
Other-Lower & \\
\hline \hline
\end{tabular}

\footnotetext{
${ }^{23}$ Since all individuals have a higher education, only the two lasts digits are reported. Individuals' ISCED first digits are 5, 6 or 7 .

${ }^{23}$ The first 9 occupational categories correspond to jobs for which a higher education is "required" while for the last two, i.e. Clerks and other-lower, a lower educational level is "required".
} 


\section{Appendix B: Wage premium by educational field and coun- try.}

Table 8: Wage-premium by educational field relative to Arts-Humanities graduates for each country and absolute distances in allocation.

\begin{tabular}{l|rrrrrrrrr}
\hline \hline $\ln w_{j 1, c}^{o b s}=\alpha_{j, c}$ & \multicolumn{1}{c}{ It } & \multicolumn{1}{c}{$\mathrm{Sp}$} & $\mathrm{Fr}$ & $\mathrm{Au}$ & $\mathrm{Nl}$ & $\mathrm{UK}$ & $\mathrm{Fi}$ & \multicolumn{1}{l}{$\mathrm{Ge}$} & \multicolumn{1}{c}{$\mathrm{Jp}$} \\
\hline Arts-Humanities (1) & - & - & - & - & - & - & - & - & - \\
Social-Sciences (2) & .10 & .03 & -.00 & -.01 & .12 & .05 & -.02 & .11 & .01 \\
Business (3) & .26 & -.02 & .23 & .19 & .10 & .09 & .21 & .12 & .00 \\
Law (4) & .17 & -.12 & .06 & -.07 & .19 & .12 & .15 & -.04 & .03 \\
Natural-Sciences (5) & .13 & .09 & .30 & .11 & .13 & .10 & .05 & .04 & .14 \\
Engineering (6) & .28 & .14 & .13 & .08 & .06 & .17 & .16 & .15 & .09 \\
Health (7) & .15 & -.09 & .13 & -.00 & .02 & .14 & .11 & -.05 & .14 \\
\hline $\bar{A}_{c}$ & 7.16 & 7.21 & 8.22 & 8.55 & 8.35 & 6.49 & 6.82 & 6.47 & 10.57 \\
\hline \hline
\end{tabular}

The wage-premia by educational field relative to Arts-Humanities graduates for each country are derived from separate estimations of the earnings regression (equation 12) for each country.

The average absolute distances between the allocation of each country and the nine-country average allocation are measured as specified in equation 11. 
Appendix C: Derived educational and occupational changes. 
Table 9: Education-specific changes in allocation after controlling for demand and supply differences.

\begin{tabular}{l|rrllllllrr}
\hline \hline $\ln \left(S_{j, c} / S_{7, c}\right)$ & \multicolumn{1}{l}{ It } & \multicolumn{1}{l}{$\mathrm{Sp}$} & $\mathrm{Fr}$ & $\mathrm{Au}$ & $\mathrm{Nl}$ & $\mathrm{UK}$ & $\mathrm{No}$ & \multicolumn{1}{l}{ Fi } & \multicolumn{1}{l}{$\mathrm{Ge}$} & \multicolumn{1}{l}{ Jp } \\
\hline Arts-Humanities & 0.15 & 0.48 & -2.98 & -1.18 & 0.26 & -1.05 & 2.09 & -0.70 & 0.28 & -0.98 \\
Social-Sciences & 0.24 & -0.20 & -4.03 & -0.69 & 0.73 & -0.89 & 2.32 & -0.36 & 0.86 & -0.72 \\
Business & 0.48 & 0.32 & -4.07 & -1.06 & 0.17 & -0.41 & 3.79 & -0.37 & -0.61 & -0.17 \\
Law & 0.18 & 0.10 & -3.87 & -0.96 & 0.79 & 0.35 & 2.60 & 0.32 & 0.91 & -0.65 \\
Natural-Sciences & 0.30 & -0.10 & -3.82 & -1.44 & 1.13 & -1.00 & 2.22 & -0.69 & -0.37 & 0.10 \\
Engineering & -0.13 & -0.23 & -2.94 & -1.54 & 0.82 & -0.13 & 1.84 & -0.77 & -0.27 & -0.60 \\
Health & - & - & - & - & - & - & - & - & - & - \\
\hline \hline
\end{tabular}


Table 10: Occupation-specific changes in allocation after controlling for demand and supply differences.

\begin{tabular}{l|rrrrrrrrrr}
\hline \hline $\ln \left(R_{1, c} / R_{i, c}\right)$ & \multicolumn{1}{l}{ It } & \multicolumn{1}{l}{$\mathrm{Sp}$} & $\mathrm{Fr}$ & $\mathrm{Au}$ & $\mathrm{Nl}$ & $\mathrm{UK}$ & $\mathrm{No}$ & $\mathrm{Fi}$ & $\mathrm{Ge}$ & $\mathrm{Jp}$ \\
\hline Leg-manager & \multicolumn{1}{l}{-} & - & - & - & - & - & - & - & - & - \\
Sciences & 1.15 & 0.22 & 0.66 & 0.88 & -0.75 & -0.79 & 0.45 & 0.10 & 0.46 & 1.04 \\
Engineering & 0.65 & 0.35 & 0.12 & 1.36 & -0.40 & -0.68 & 0.45 & 0.36 & 1.11 & 0.64 \\
Health & -0.19 & 0.62 & -0.28 & 2.82 & -1.13 & -0.06 & -0.37 & 0.71 & 0.61 & 0.67 \\
Teaching & 0.91 & 0.52 & -0.04 & 1.80 & -1.94 & -1.28 & 0.73 & 1.06 & 1.06 & 0.43 \\
Business & 2.10 & -1.55 & -0.75 & 1.79 & -0.29 & -0.93 & 0.72 & 0.65 & 0.91 & -0.41 \\
Legal & 1.92 & 0.24 & -0.15 & 2.67 & -2.10 & 0.15 & -1.09 & 0.87 & 2.18 & -0.50 \\
Social-sciences & 0.47 & -0.29 & -0.35 & 2.93 & -0.67 & -1.71 & -1.22 & 0.62 & 0.98 & -1.16 \\
Arts-humanities & 0.17 & -2.15 & -1.01 & 2.17 & -1.59 & -0.93 & 2.39 & 0.62 & 1.36 & -1.33 \\
Clerks & 1.04 & 1.12 & -0.80 & 0.44 & -1.42 & -1.19 & -3.68 & -1.35 & 0.12 & 2.16 \\
Other-lower-occ & 0.46 & 0.59 & 0.05 & -0.28 & -1.69 & -0.91 & -1.75 & -0.97 & -0.55 & 2.32 \\
\hline \hline
\end{tabular}

